\title{
Influence of liver fibrosis stage on nevirapine plasma concentration in HIV-infected patients with chronic hepatitis $C$ virus
}

\author{
Gordana Dragovic ${ }^{1 *}$, Colette Smith², Djordje Jevtovic ${ }^{3}$, Mike Youle $^{4}$, David Back ${ }^{5}$ \\ From The 7th Romanian National HIV/AIDS Congress and The 2nd Central European HIV Forum \\ Sibiu, Romania. 29-31 May 2014
}

Hepatitis $\mathrm{C}$ virus (HCV) co-infection in HIV positive patients can affect the pharmacokinetics (PK) of antiretroviral drugs that are metabolized by the liver. Therefore, we determined plasma nevirapine (NVP) concentrations $\left(\mathrm{C}_{\text {trough }}\right)$ in HIV+ patients with or without HCV coinfection.

This was a prospective study in patients receiving NVP (200 mg twice daily or $400 \mathrm{mg}$ once daily) for at least 12 weeks as a part of antiretroviral regimen, at the HIV/AIDS Centre, Infective and Tropical Disease Clinic, Belgrade, Serbia. Written consent was obtained and the study was approved by the local ethics committee.

NVP plasma concentrations were measured by a validated HPLC-UV method at the University of Liverpool, UK. Statistical analysis was performed by SPSS software package.

27 patients (18 HIV mono-infected and $9 \mathrm{HCV} / \mathrm{HIV}$ co-infected patients) receiving NVP as part of their antiretroviral therapy were enrolled. The median age of the 27 patients was 43 years and all were Caucasian. In all patients HIV RNA was $<50$ copies/mL; median CD4+ T-cells count was 363 cells $/ \mathrm{cmm}$. Median NVP $C_{\text {trough }}$ was $4826 \mathrm{ng} / \mathrm{mL}(2533-8718 \mathrm{ng} / \mathrm{mL})$ in the HIV monoinfected group and $5810 \mathrm{ng} / \mathrm{mL}(4998-11783 \mathrm{ng} / \mathrm{mL})$ in the HIV/HCV co-infected group, respectively. Compared to an individual with HIV mono-infection, those with $\mathrm{HCV} / \mathrm{HIV}$ co-infection had a higher NVP trough level $(95 \% \mathrm{CI}+67 \mathrm{ng} / \mathrm{mL},+2940 \mathrm{ng} / \mathrm{mL} ; P=0.03)$. NVP plasma levels above the toxic threshold $(8000 \mathrm{ng} / \mathrm{mL})$ were more frequent in patients with liver cirrhosis than in those without ( $33 \%$ vs. $4 \% ; P<0.001)$.

'Institute of Pharmacology, Clinical Pharmacology and Toxicology, School of Medicine, University of Belgrade, Belgrade, Serbia

Full list of author information is available at the end of the article
Despite the small numbers of patients included, this PK study has shown that NVP plasma levels are impaired in HIV-infected patients co-infected with HCV, especially in those with liver fibrosis.

\section{Authors' details}

'Institute of Pharmacology, Clinical Pharmacology and Toxicology, School of Medicine, University of Belgrade, Belgrade, Serbia. ${ }^{2}$ Department of Primary Care and Population Sciences, Royal Free and University College Medical School, London, United Kingdom. Institute of Infective and Tropical Disease "Dr Kosta Todorovic", School of Medicine, University of Belgrade, Belgrade, Serbia. ${ }^{4}$ Royal Free Centre for HIV Medicine, Royal Free and University College Medical School, University College London, London, United Kingdom. ${ }^{5}$ Department of Pharmacology and Therapeutics, University of Liverpool, Liverpool, United Kingdom.

Published: 29 May 2014

\section{doi:10.1186/1471-2334-14-S4-017}

Cite this article as: Dragovic et al:: Influence of liver fibrosis stage on nevirapine plasma concentration in HIV-infected patients with chronic hepatitis C virus. BMC Infectious Diseases 2014 14(Suppl 4):017.

Submit your next manuscript to BioMed Central and take full advantage of:

- Convenient online submission

- Thorough peer review

- No space constraints or color figure charges

- Immediate publication on acceptance

- Inclusion in PubMed, CAS, Scopus and Google Scholar

- Research which is freely available for redistribution

Submit your manuscript at www.biomedcentral.com/submit
() Biomed Central 